In the 10 years since he moved to Oxford's Institute of Archaeology, he had resumed work in Libya, directing rescue excavations for the Society of Libyan Studies with a colleague from Benghazi's Gar Yunis University at Euhesperides, the first Greek colony at Benghazi. Their excavations demonstrated that the city was founded earlier than supposed, in the 6th c. B.C., surviving till it was replaced by Berenice in the 3rd c. B.C., as well as illuminating how the new colony was supported by its agricultural hinterland, its trading contacts with the eastern Mediterranean, and the processes of social interaction between incoming Greeks and indigenous Libyans. He also continued his field research on the Samnites, directing a major survey and excavation project in the Sangro valley with colleagues from Italy, Oxford, and Leicester, culminating in the excavation of a Samnite hillfort settlement, Monte Pallano (see his article with A. Faustoferri, "Monte Pallano: a Samnite fortified centre and its hinterland," JRA 11 [1998] 5-22). It was during his final scheduled season of fieldwork in the Sangro valley, in September 1998, that he was first taken ill with what transpired to be a brain tumour.

John Lloyd was an exceptionally modest man who constantly downplayed his achievements, but his archaeology was characterized by meticulous and careful scholarship made to last, whether in his own research or as a gifted and painstaking editor for the publications of the Society for Libyan Studies and the British School at Rome. That he achieved such remarkable and enduring results in his Libyan, Greek and Italian fieldwork was in part because of the modesty, sensitivity and integrity he brought to his professional relations. He had a tremendously strong sense of the importance of doing the right thing by his collaborators, his colleagues in the UK and abroad, his authors, his field teams, the students he taught at Sheffield and Oxford, and the family of which he was so proud. In addition, he had a remarkable gift for spotting rising young talent in Libyan and Italian archaeology and offering advice and encouragement. Many people other than his own students thus benefitted from his generosity and gentle patronage. He set standards of professionalism few archaeologists emulate; his fieldwork has given us new understanding of ordinary life in towns, villages and farms throughout the ancient world; and in his caring for the profession of archaeology, and how it should be performed to the highest standards, he had a profound influence on the careers of scores of archaeologists in Britain and abroad fortunate enough to be touched by his wisdom and wit.

Graeme Barker, with David Mattingly

\title{
A NOTE ON THE REVIEW OF SATRICUM BY C. J. SMITH (pp. 453-75 below)
}

As C. J. Smith correctly remarks at the end of his review article, further exciting developments are to be expected from the new excavations at Satricum and indeed are already occurring as a result of two years of research in the lower settlement area, northwest of the acropolis. This area has yielded many remains that are of particular importance for both the later history of the town and for the presumed Volscian presence. The finds testify to the continuity of the settlement during the 5th and 4th c. B.C. (and presumably to the continuity of its central sanctuary), finally putting an end to discussions as to whether after 500 B.C. Satricum had become merely a place for pilgrims or whether it even continued to exist. More graves dating to the 5th c. have also been recorded, while new data have been obtained pertaining to their Volscian identification and for the Volscian presence in general. A new publication analysing all finds of the 5 th $\mathrm{c}$. is now in preparation, and we hope to present a summary of the latest finds in JRA 13 (2000). 